\title{
ジルコニア強化結晶化ガラスの組織と生体活性機能
}

春日 敏宏计 2 , 宇野 智子放 1 , 吉田 昌弘的1 越阪部基延的 1 , 生嶋 明的 1

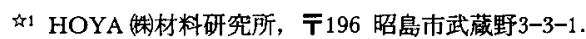

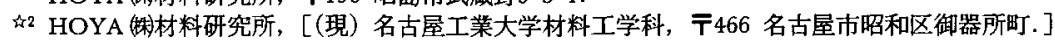

\section{Microstructure and Bioactivity of Zirconia-toughened Glass-ceramics}

\author{
Toshihiro Kasuga ${ }^{\Uparrow 2}$, Tomoko Uno ${ }^{\Uparrow 1}$, Masahiro Yoshida \\ Kinobu Osakabe ${ }^{\text {in } 1}$ and Akira J. Ikushima ${ }^{\text {ir } 1}$ \\ \{11 Materials Research Laboratory, Hoya Corporation, 3-3-1 Musashino, Akishima 196. \\ \$2 Hoya Corporation, [Present Address: Dept. Mater. Sci. \& Engng., Nagoya Institute of Technology, \\ Gokiso-cho Showa-ku, Nagoya 466.]
}

Bioactivity of zirconia-toughened glass-ceramic composites was evaluated in terms of their surface reaction in simulated body fluid. The bioactivity was degraded by introducing large amounts of zirconia. TEM observation revealed that $\mathrm{Ca}$ in the glass-ceramic particles reacted with the zirconia during sintering, and that the decrease in $\mathrm{Ca}$ in the particles degraded the bioactivity of the composites. In this study, the optimum composition and preparation process are determined for highstrength and bioactive ceramics.

\section{1 粕 言}

Bioglass ${ }^{\mathrm{TM}}$ と呼ばれる生体骨と直接化学結合する (生体活性) ガラス材料がHench ${ }^{11}$ によって開発され て以来, 種々の生体活性セラミックスが提案されて いる.アパタイトとウォラストナイトを含有する $\mathrm{Ca} 0-\mathrm{P}_{2} \mathrm{O}_{5}-\mathrm{SiO}_{2}-\mathrm{Mg} 0$ 系結晶化ガラスは, 高い生体活 性機能を持ち、比較的高い強度 (曲げで200〜250MPa) を示す ${ }^{2)}$.しかし，人工菌根のように用途によって は, 非常に高い強度が要求されることがある.我々 は，広範囲な用途開発のために，この結晶化ガラス をジルコニアで強化したコンポジットを作製したこ

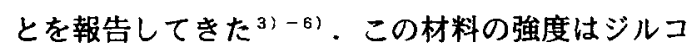
ニア添加量の增大とともに向上し，たとえば，30
vo1\%のジルコニア添加で600MPa，50vol\%で800MPaと いう高い曲げ強度を示す5)。

ジルコニア強化結晶化ガラスは結晶化ガラス粉末 とジルコニア粉末の混合物を焼結して得られる ${ }^{61}$. 結晶化ガラス粉末およびジルコニア粉末の焼結性や 粒径を変化させることにより, 得られる焼結体の微 構造が異なることを報告している315)．すなわち，

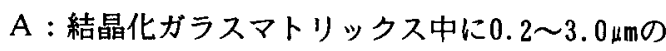
ジルコニア焼結体粒子が分散された構造のものと,

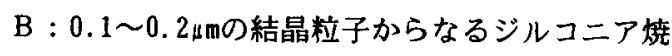
結体マトリックス中に結晶化ガラス粒子が分散さ れた構造のもの,

の2タイプの焼結体が得られる(以下，それぞれ， 
複合結晶化ガラス A, 複合結晶化ガラス B と称す). このような組織の違いは生体活性機能に影響を及田 すことが予想される.本研究では，インビトロ法を 用いてジルコニア強化結晶化ガラスの組織形態の違 いが生体活性機能に及ほす影響を調べた。

\section{2 実唋方法}

\section{1 試料の調製}

生体活性結晶化ガラスの親ガラスとジルコニア 粉末 ${ }^{91}$ の組成をTable 1 に示した.この親ガラスは, Table 1 のバッチ混合物を白金坩堝中1550てで1時間 溶融し急冷して得た．複合結晶化ガラス A, Bの作 製方法の詳細は先に報告されているが，概ね以下の とおりである。

\section{(a) 複合結晶化ガラス $A^{3) 4 / 51 ~}$}

先ず、ジルコニア粉末を相対密度 $99 \%$ 以上で焼 結させておき，これを平均 $1 \mu \mathrm{m}$ 程度まで粉砕したも のを親ガラスと混合した。これらの粉砕，混合には ジルコニアボールミルを用い,エタノールを用いて 湿式で行った。この混合粉末を1150て，2時間カーボ ン型に入れ，ホットプレス焼成して複合結晶化ガラ スAを得た．したがって，複合結晶化ガラスAはガ ラスの粘性流動によって䌁密化される。

(b) 複合結晶化ガラス $B^{6)}$

親ガラスを1150て, 2時間再加熱して結晶化させた。 この結晶化ガラスは約15\%のアパタイトと約70\%のウ オラストナイトを含有する.これを平均 $1 〜 2 \mu \mathrm{m} の$ 粒 度にまで粉砕した.この粉末結晶化ガラスとジルコ

Table 1. Compositions of Raw Materials

\begin{tabular}{cl}
\hline \multicolumn{1}{c}{ Glass } & Zirconia* $^{*}$ \\
\hline $\mathrm{Ca} 0: 47.7$ (wt\%) & $\mathrm{Y}_{2} 0_{3}: 4.65$ (wt\%) \\
$\mathrm{SiO}_{2}: 43.8$ & $\mathrm{ZnO}: 0.19$ \\
$\mathrm{P}_{2} 0_{5}: 6.5$ & $\mathrm{SiO}_{2}:<0.1$ \\
$\mathrm{Mg} 0: 1.5$ & $\mathrm{TiO}_{2}:<0.1$ \\
$\mathrm{CaF}_{2}: 0.5$ & $\mathrm{Al}_{2} 0_{3}:<0.01$ \\
& $\mathrm{Fe}_{2} 0_{3}:<0.01$ \\
& $\mathrm{ZrO}_{2}:$ bal. \\
\hline
\end{tabular}

*BET specific area of $15 \sim 17 \mathrm{~m}^{2}$, Nippon Soda Co.
ニア粉末をエタノール中でボールミル混合した，乾 燥した混合粉末を泠間等方加圧成形 (CIP)し，これ を1200て.2時間锛成し，予供焼成体とした。この予 備焼成体をさらに1200て.1時間, 196MPaでポストシン タリングして複合結晶化ガラスを得た．このように, 複合結晶化ガラスBは，ほぼシルコニア粉末の焼結 により緻密化される。

\section{2 評価方法}

生体活性なガラス, 結晶化ガラス, セラミックス は，擬似体液中でその材料表面にアパタイトを形成 することが報告されている7!．このアパタイト形成 能力は生体活性と関係がある。この方法は, 系統的 な組成の変化に対する生体活性の変化を予想できる ものである ${ }^{81}$ 。そこで， $37^{\circ} \mathrm{C}$ の擬似体液中に28日浸 漬した後、アパタイトの表面に生成能力を $\mathrm{X}$ 線回折 により調べた，擬似体液に浸漬する前のアパタイト の (002) の回折強度 $\left(I_{b}\right)$ と擬似体液浸漬後の回折強 度 $\left(I_{a}\right)$ を測定し，ここでは $I_{a} / I_{b}$ をアパタイトの 生成能力と定義した。擬似体液は, $\mathrm{Na}^{+} 142.0, \mathrm{~K}^{+}$ 5.0, $\mathrm{Mg}^{2+} 1.5, \mathrm{Ca}^{2+} 2.5, \mathrm{Cl}^{-} 148.8, \mathrm{HCO}_{3}^{-} 4.2$, $\mathrm{HPO}_{4}{ }^{2-1.0}(\mathrm{mM})$ に, トリスヒドキシメチルアミノ メタン $50 \mathrm{mM}$ ，塩酸 $45 \mathrm{mM}$ 添加して $\mathrm{pH} 7.3 に$ 調整した 水溶液である。試料のサイズは $15 \times 15 \times 1 \mathrm{~mm}^{3}$ とし， 水溶液は $100 \mathrm{~m} 1$ とした。

通常のイオンシニング法によって得られた薄片を 用いて複合結晶化ガラスの組織を透過電子顕微鏡 (T EM) 観察した. X 線エネルギー分散分光法 (EDS)によ り組成分析も行なった。

\section{3 結果と考察}

Fig.1は, 複合䊅晶化ガラスのジルコニア含量と 擬似体液中でのアパタイト生成能力の関係である。 このアパタイト生成能力は, 複合結晶化ガラス中の 結晶化ガラス含有率が少なくなっても，結晶化ガラ スそのものの生体活性機能が低下していなければ一 定値を示すはずである．複合結晶化ガラスAについ ては, ジルコニア量 (Vf) 40vo1\%までアパタイト生成 能力の低下は見られなかったが，50vo1\%以上になる と急激に低下した。一方，複合結晶化ガラス Bのア パタイト生成能力は, ジルコニア量が增すにつれ徐 
徐に低下した.なお, 犬の頸骨または大腿骨に試料 を埋入し, 2 力月後の骨との接合力を調べると, 複 合結晶化ガラス B (Vf 30\%) は結晶化ガラスと同程度 に骨組織と強く結合していたが, 複合結晶化ガラス B (Vf50\%)の生体活性はかなり低下し, 骨との接合 強度は結晶化ガラスのそれの $1 / 5$ 以下であった。

Fig.2は, ジルコニアVf $30 \%, 50 \% の$ 複合結晶化ガ ラスのTEM写真である. EDSより, 結晶化ガラスは明 るく見え, ジルコニアはやや暗く見える粒子である. 複合結晶化ガラス A, B ともに, Vf $50 \%$ にるとジ ルコニア粒子が結晶化ガラスを取り囲んだ構造にな ってくる. Kokubo ${ }^{10)}$ によれば, 結晶化ガラスの生 体活性は結晶化ガラス中のガラス相, ウォラストナ イト相から $\mathrm{Ca}^{2+}, \mathrm{HSiO}_{3}$-イオンが生体内に溶け出し, 生体液中のイオンと反応することによって達成され る. 結晶化ガラスが完全に閉じ込められると生体液

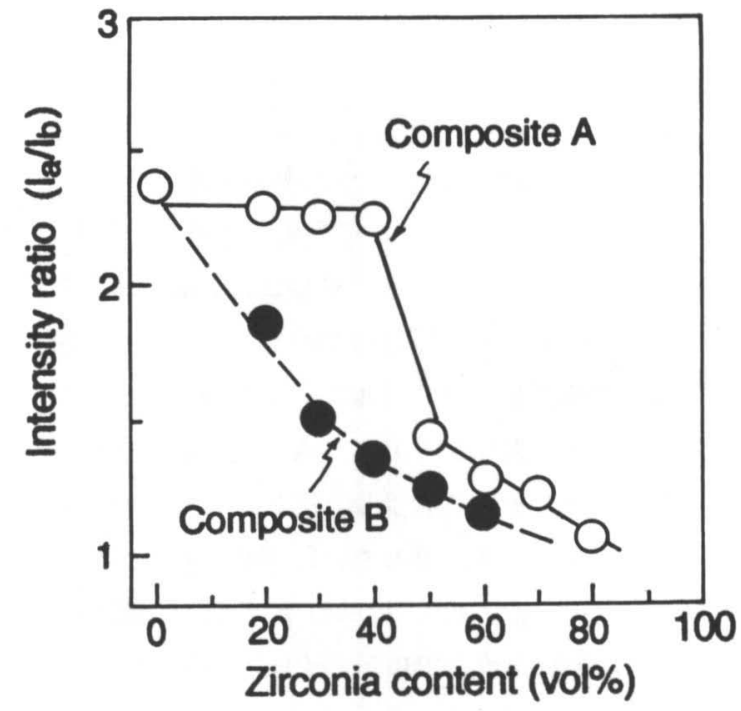

Fig.1 X-ray diffraction intensity ratio of apatite crystal (Ia/Ib) before and after in vitro test.
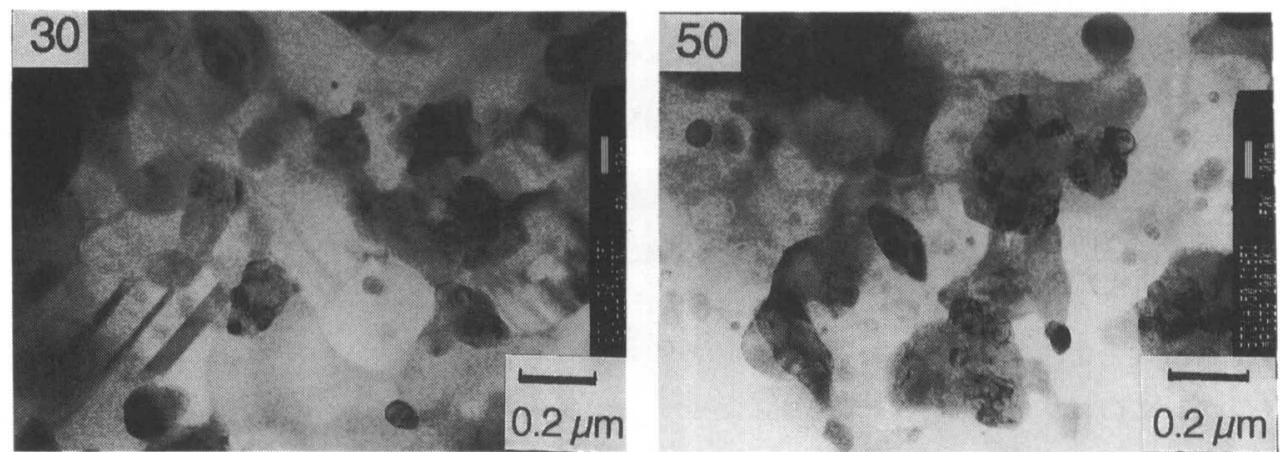

\section{Composite A}
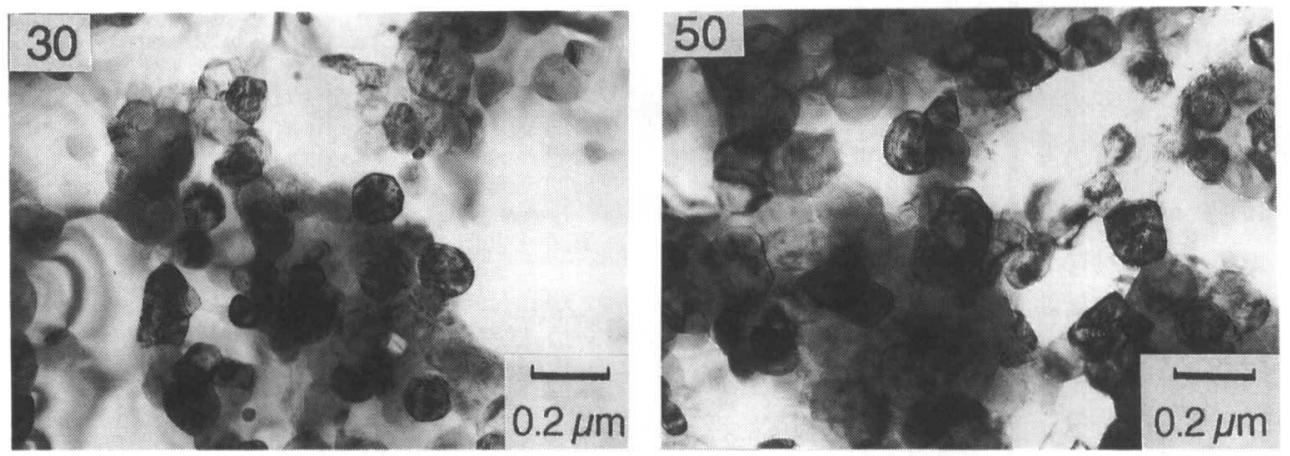

Composite B

Fig. 2 TEM photographs of the composites. Numbers in the photos indicate zirconia content (vol\%). 
と結晶化ガラス粒子とが反応することができなくな り, 複合結晶化ガラスとしての生体活性機能が低下 することになる．

Fig.3は, 複合結晶化ガラス中の結晶化ガラス部 分のCa，SiをEDSにより組成分析した結果である.

複合結晶化ガラスAでは，ジルコニア量が増すと若 干のCa量の減少, Si量の増加があった。一方，複合 結晶化ガラス Bでは, ジルコニア量が增すにつれて 組成が大きく変化しており，Aとはかなり異なって いた.Ca量が極端に減少し，その結果Si量が増加し ている.なお，A，Bとも，P，Mgについてはほと んど变化はなかった，Ohtsukiら"'は，Ca量が少な くSi量の多いガラスではアバタイトが生成しにくく なることを報告している．アパタイトの生成能力の 低下は，作製工程で生じたCa星の减少による影響が 大きいと考えられる．複合結晶化ガラス B の場合， ジルコニア粒子が焼結する際に，結晶化ガラス粒子 と反応して結晶化ガラス中のCa濃度が減少する ${ }^{81}$. 一方，2.1で述べたように，複合結晶化ガラス Aで は，ほとんどジルコニアと結晶化ガラスの反応はみ られない，この違いは複合結晶化ガラスAとBの作 製方法が大きく異なることに起因している．複合結 晶化ガラスAでは，予め一旦焼結させたジルコニア をガラスマトリックスに分散させる方法をとってい る.すなわち, 緻密化はガラス自身の粘性流動のみ によるもので, このガラス粉末の焼結後結晶化させ る.したがって, ジルコニアの新たな焼結は起らな い.

我々は先に, 結晶化ガラス単味と複合結晶化ガラ ス $\mathrm{B}$ の生体内での強度の変化について犬の皮下に埋 入して調べた結果を報告している ${ }^{22}$ ．結晶化ガラ スは体液との反応層の厚さが埋入期間とともに厚く

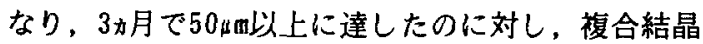
化ガラスBでは，3カ月で $10 \mu \mathrm{m}$ 程度であった，結晶化 ガラスの強度は低下の傾向を示したが, 複合結晶化 ガラスBではほとんど低下しなかった。結晶化ガラ スからのイオンの溶出と反応層の生成は強度を低下 させる可能性が高い。複合結晶化ガラスAは,ジル コニア粒子が結晶化ガラスマトリックス中に埋め込 まれた構造をしているので, 結晶化ガラスからのイ

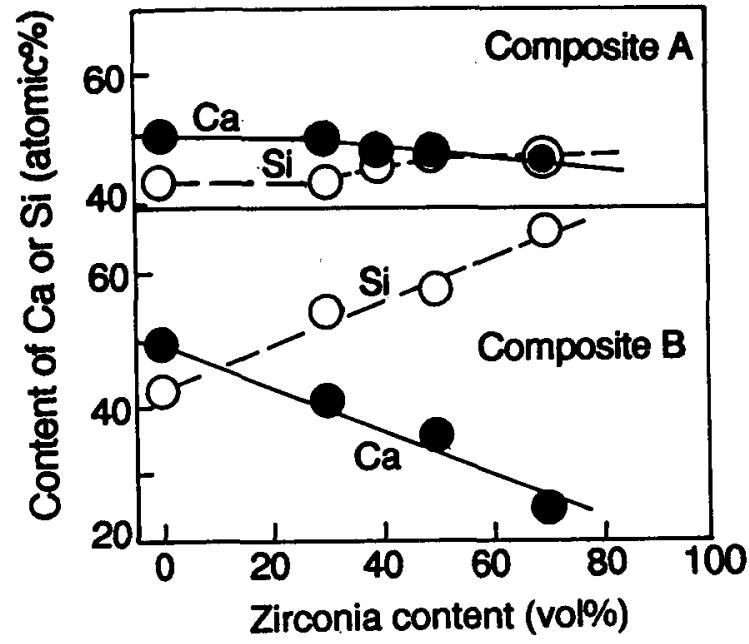

Fig.3 $\mathrm{Ca}$ and $\mathrm{Si}$ contents in the glass-ceramic particles in the composites analyzed by EDS.

オンの溶出と生体液との反応による強度の変化に留 意しておく必要がある。

\section{4 結 詥}

複合結晶化ガラスAは，結晶化ガラスの高い生体 活性機能を維持できるものの, 生体内での強度の低 下が懸念される，一方，複合結晶化ガラス B は, や や生体活性が低下するものの, 強度低下しにくいと 考えられるので，長期に渡って使用できる高強度バ イオセラミックスとして好ましいであろう.

\section{文 献}

1) L.L. Hench: Proc. 10th Intern' 1 Cong.Glass, (1974) No. $9,30$.

2) T.Kitsugi, T. Yamamuro, T. Nakamura, T. Kokubo: J. Biomed. Mater. Res., 23 (1989) 631.

3）中島紀一,春日敏宏:弪吹論文誌, 97 (1989) 256.

4) T.Kasuga, K. Nakajima: Clin. Mater., 4 (1989) 285.

5) T. Kasuga, K. Nakajima: Bioceramics 2, (1990) 303.

6) T.Kasuga, K. Nakajima, T. Uno, M. Yoshida: J. Am. Ceram. Soc. , 75 (1992) 1103.

7) T.Kokubo, T.Hayashi, S. Sakka. T.Kitsugi. T. Yamamuro, M. Takagi. T.Shibuya: Ceramics in Clinical Applications, Elsevier, (1987) 175.

8) T. Kasuga, M. Yoshida, A.J. Ikushima, M. Tsuchiya, G. Kusakari : J.Am. Ceram. Soc. , 75 (1992) 1884.

9) N. Kimura, H.Okamura, J. Morishita: Advanced Ceramics 24, American Ceramic Society. (1988) 183.

10) T. Kokubo: Handbook of Bioactive Ceramics 1, CRC Press, (1990) 41.

11) C.Ohtsuki, T.Kokubo, K. Takatsuka, T. Yamamuro: J. Ceram. Soc. Jpn., 99 (1991) 1.

12) T. Kasuga, M. Yoshida, A.J. Ikushima. M. Tuchiya, H. Kusakari: Materials in Medicine. (1992) in press. 